\title{
Electronic Journal of Plant Breeding
}

\section{Rice ADT 51 - A high yielding long duration rice variety suitable for Samba season in Cauvery Delta Zone of Tamil Nadu}

\author{
R. Suresh, R. Parthasarathy, R. Vaithialingam, D. Sassikumar, \\ R. Saraswathi, S. Santha, R. Pushpa, S. Suresh, K. Rajappan, \\ K. Subramanian and V. Ravi.
}

Tamil Nadu Rice Research Institute, Tamil Nadu Agricultural University, Aduthurai - 612 101, Tamil Nadu, India. E-Mail: sureshpbg@gmail.com

\begin{abstract}
In Tamil Nadu, rice is the predominant crop during samba season. In the Cauvery Delta Zone around 2.5 lakh hectares purely depend on water from Cauvery in Samba season during the normal years of water release from Cauvery, CR 1009 is predominantly grown variety without any alternate varieties. Mono cropping of CR 1009 leads to susceptibility to pests such as brown plant hoppers (BPH) stem borers and diseases such as blast, bacterial leaf blight (BLB), grain discolouration and false smut. In order to provide a choice variety to farmers' one long duration rice culture, AD 09367 a derivative of the cross BPT 5204 / Improved White ponni was released as Rice ADT 51 during the year 2018. ADT 51 matures in 155 to 160 days with tall, erect and high tillering plant habit and well adapted to single season canal dependent rice growing areas of Cauvery delta for Samba season (August-September sowing). ADT 51 has recorded a mean grain yield of $6533 \mathrm{~kg} / \mathrm{ha}$ which is 9.8 and 12.7 per cent higher than CR $1009(5947 \mathrm{~kg} / \mathrm{ha})$ and ADT 50 (5796 $\mathrm{kg} / \mathrm{ha}$ ) respectively. At Thiruvisanallur, Thanjavur district it manifested highest yield of $10036 \mathrm{~kg} / \mathrm{ha}$ and the OFT farmer, Mr. Baskar received first prize in the district level crop yield competition for the year 2016. Besides its yield superiority, ADT 51 is resistant to blast and moderately resistant to leaf folder, stem borer, BPH, Sheath blight and sheath rot. The milled rice of this variety is white, medium grade with a 1000 grain weight of $23.9 \mathrm{~g}$. High milling and head rice yield and cooking qualities of ADT 51 are comparable with CR 1009. Opinion from farmers revealed that, vigorous growing nature and tolerance to major pest and diseases of this culture requires less inputs especially nitrogenous fertilizer and plant protection chemicals for cultivation. The characters such as more no. of productive tillers, less chaffiness and quick establishment of seedling are its added advantages.
\end{abstract}

Key words

ADT 51, long duration, short duration.

\section{INTRODUCTION}

Rice is a staple food for over half of the world's population (FAO, 2004). Rice accounts for over 20 per cent of global calorie intake. Over 90 per cent of the world's rice is produced and consumed in the Asian Region comprising $80 \%$ of the world's production and consumption. It is grown on 154 million hectares world-wide in a wide range of environments. In India, rice is grown in an area of 45 million ha (23\% of gross cropped area) with an annual production of 90 million tonnes (Viraktamath and Sundaram, 2010). In Tamil Nadu, total area under rice is 18.30 lakh hectares, production of 58.39 lakh tonnes and with a productivity of $3190 \mathrm{~kg} / \mathrm{ha}$ during 2014-15 (INDIASTAT, 2015). Among the Indian states Tamil Nadu has highest productivity of $3.92 \mathrm{t} / \mathrm{ha}$.

On average, rice accounts for nearly half of the food expenses of poor people and a fifth of their total household expenses. It is well established that the rapid productivity growth of rice resulting from the use of improved varieties, fertilizers, and irrigation (popularly known as the Green Revolution) increased the production and led to a longterm decline in rice prices. This has been the major factor 
helping to reduce poverty in Asia over the past several decades. Despite the past achievements, rice productivity growth will remain essential in the future for several important reasons. Nearly all rice farmers worldwide depend on rice varieties that have been improved by scientific breeding since the Green Revolution (Sushil Pandey et al., 2010).

Improvement in the yield potential of rice is the major strategy to increase world rice production. Increase in grain yield potential is the major goal of almost all rice breeders' programs. Rice breeders have been very successful in improving the crop. Some milestones are the contribution to the green revolution with the semi-dwarf varieties, the new rice plant type and hybrid rice. In the dynamic ricebreeding programme, genotypes with improvement in grain yields or in other traits of economic value compared to checks are identified through replicated multi-location trials across rice growing environments and released as varieties for commercial cultivation (Muralidharan et al., 2019). During evaluation, yield, grain quality and resistance to biotic and abiotic stresses are ranked; breeding lines that show superiority compared to check cultivars are then selected for release (Lin et al., 1986).

On the other hand, based on the performance of the varieties and also based on the emerging needs of the farmers, traders and end users, the old varieties are to be replaced time to time. Such a breeding effort was made at Tamil Nadu Rice Research Institute, Aduthurai to develop a long duration rice variety suitable for Cauvery Delta Zone of Tamil Nadu as a choice variety to CR 1009.

In Cauvery Delta Zone, during Samba season rice cultivation in an area of 2.5 lakh hectares purely depends on water from Cauvery and rice is cultivated in single season. In these areas during the normal years of water release from Cauvery CR 1009 is predominantly grown without any alternate varieties. Mono cropping of CR 1009 leads to susceptibility to pests such as brown plant hoppers (BPH), stem borers and diseases such as blast, bacterial leaf blight (BLB), grain discoloration and false smut.

From 1980 to 2016,14 rice varieties were released by Tamil Nadu Rice Research Institute, out of which only three (ADT 40, ADT 44 and ADT 50) were released for Samba season with the duration of more than 145 days. Among the long duration varieties, the most popular one is CR 1009 and other varieties are less popular among the farmers.

In order to offer the farmers to have wider choice of varieties for cultivation during single crop Samba season, research efforts were undertaken at this institute with an objective to develop a rice variety suitable for Samba season which resulted in the development of a medium slender high yielding long duration rice culture AD 09367 and released as ADT 51 during, 2018. ADT 51, a cross derivative of BPT 5204 / Improved White Ponni has the maturity duration of 155 to 160 days with tall, erect and high tillering plant habit. It has long panicles with more filled grains and angular boot leaf and best suited for Samba season (August-September sowing).

\section{MATERIALS AND METHODS}

ADT 51 is a derivative of the cross BPT 5204 / I. W. Ponni effected during 2004 and advanced upto $\mathrm{F}_{4}$ in Tamil Nadu Rice Research Institute, Aduthurai. Homozygous culture was identified in $\mathrm{F}_{4}$ generation during Samba, 200809 and tested in various yield trials as AD 09367 from Samba, 2009-10 to 2016-17 (Fig 1). Based on the yield performance of this culture in station trials it was nominated for testing in Multi-Location trials during 2012 to 2014 . As the performance of this culture was satisfactory in the MLT trials it was recommended for testing in Adaptive Research Trial (ART) for a period of two years (2014-15 to 2015-16). Under ART this culture was tested in 10 locations each in eight districts viz., Trichy, Thanjavur, Nagapattinam, Tiruvarur, Cuddalor, Pudukkottai, Karur and Perambalur. ARTs were also conducted in three locations each in five Krishi Vigyan Kendras viz., Nagapattinam, Thiruvarur, Pudukkottai, Trichirapalli and Cuddalore during 2014-15 and 2015-16. AD 09367 was also evaluated in All India Coordinated Rice Improvement Programme (AICRIP) trials as IET 23617 in Initial Varietal Trial - Late (IVT-L) during Kharif, 2013. Besides various trials conducted in research stations, large no. of On Farm Trials (OFTs) were also conducted in farmer's field at 107 locations. Pest and disease performance was tested under artificial and field conditions at Aduthurai, Coimbatore and Madurai. Quality parameters viz., Physical, cooking and biochemical properties of this culture was tested along with CR 1009 at TRRI, Aduthurai and Department of Rice, TNAU, Coimbatore

\section{RESULTS AND DISCUSSION}

The culture AD 09367 recorded a mean grain yield of $6796 \mathrm{~kg} / \mathrm{ha}$ in the yield evaluation trials at Tamil Nadu Rice Research Institute, Aduthurai from 2009 to 2015. The yield increase was 15.2 and 9.1 per cent respectively over the checks CR 1009 (5897 kg / ha) and ADT 50 (6229 kg / ha). In Multi Location Trials conducted during 2012-13 and 2013-14 at different research stations the mean grain of $7242 \mathrm{~kg}$ / ha was recorded in the AD 09367 with yield increase of 6.8 and 10.0 per cent over CR 1009 (6778 kg / ha) and ADT 50 (6584 kg / ha) respectively. AD 09367 was evaluated as IET 23617 under All India Coordinated Rice Improvement Programme during 2013 under Initial Varietal Trial - Late, in which the culture registered superior performance in Shirgaon, Nellore and Karaikal locations than the national check Swarna.

Adoptive Research Trial (ART) was conducted during 2014-15 and 2015-16 in 10 locations each in 8 districts namely Thanjavur, Tiruvarur, Nagapattinam, Cuddalore, Pudukkottai, Trichy, Perambalur and Karur. Over two years of ART in 77 locations, this culture recorded mean grain yield of $6444 \mathrm{~kg} / \mathrm{ha}$ which is 3.9 per cent higher than CR 


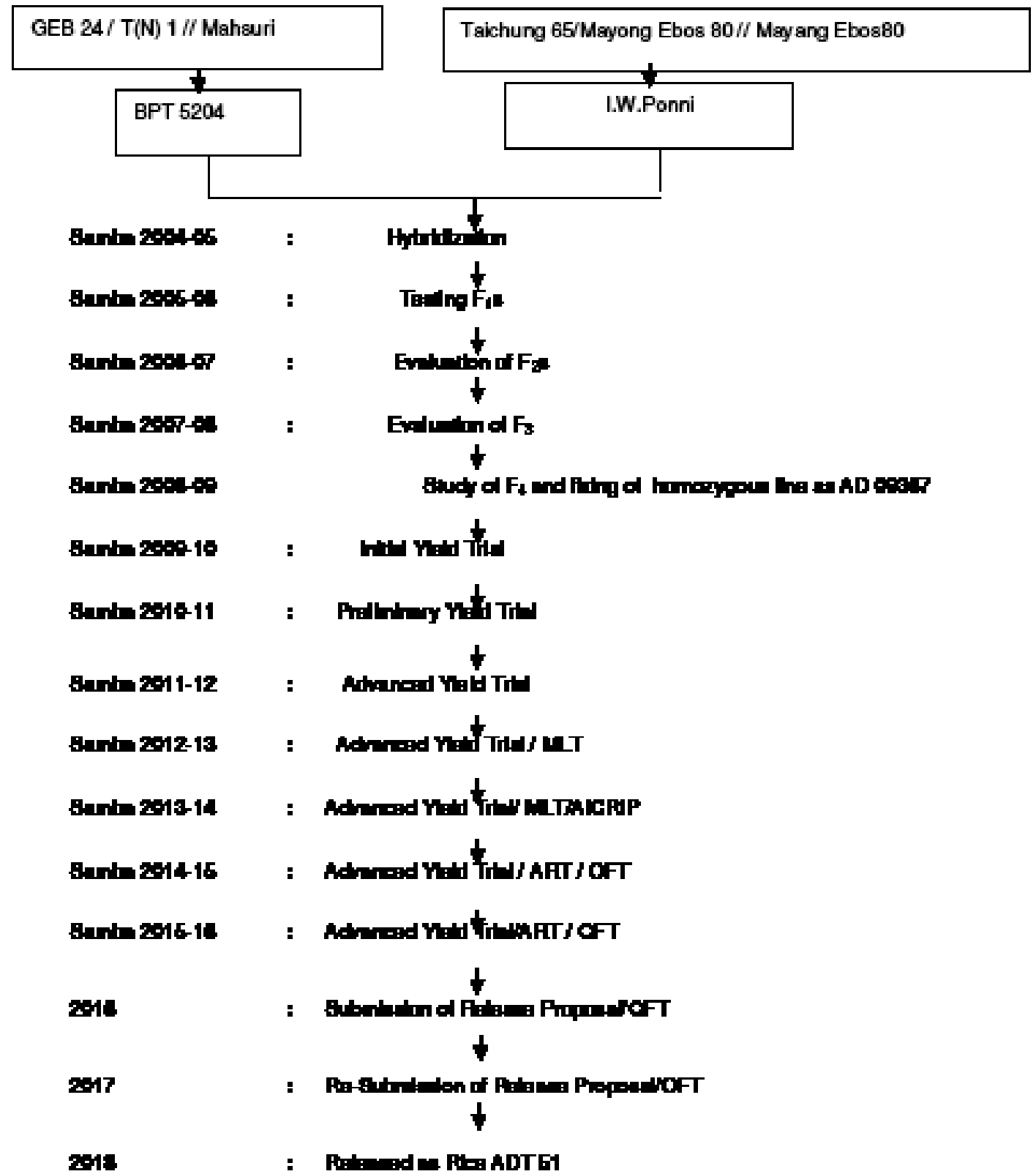

Fig.1. Pedigree of AD 09367 (IET 23617)

1009 (6202 kg / ha) and 11.1 per cent higher than ADT 50 (5798 kg / ha). In ART Trials conducted through Krishi Vigyan Kendras it recorded a mean grain yield of $6206 \mathrm{~kg}$ / ha which was 8.6 and 8.0 per cent higher than CR 1009 (5713 kg / ha) and ADT 50 (5741 kg / ha) respectively.

In the On Farm Testing (OFTs) conducted in 107 farmer holdings in three delta districts during 2014-15 to 2016-17, the AD 09367 recorded the mean grain yield of $6709 \mathrm{~kg}$ I ha which is 15.7 per cent higher than the check variety CR 1009 (5797 kg / ha). The overall mean performance of AD 09367 against the checks viz., CR 1009 and ADT
50 in different yield trials is given in Table 1. The culture has recorded a mean grain yield of $6533 \mathrm{~kg} /$ ha at 191 locations which was 9.8 and 12.7 per cent increased grain yield over CR 1009 (5947 kg / ha) and ADT 50 (5796 kg / ha) respectively. Highest yield of this culture was realized at Thiruvisanallur in Thanjavur district, where it manifested $10035 \mathrm{~kg} / \mathrm{ha}$. The OFT farmer, Mr. Baskar received first prize in the crop yield competition for the year 2015-16.

AD 09367 was screened against the important diseases viz., blast, bacterial Sblight, sheath rot, sheath blight and brown spot under artificially inoculated conditions 
Table 1. Overall yield performance of ADT 51 (AD 09367) in different yield trials

\begin{tabular}{|c|c|c|c|c|c|c|c|c|}
\hline \multirow{2}{*}{$\begin{array}{l}\text { S. } \\
\text { No }\end{array}$} & \multirow[t]{2}{*}{ Name of the Trials } & \multirow{2}{*}{$\begin{array}{c}\text { No. of } \\
\text { Locations }\end{array}$} & \multicolumn{3}{|c|}{ Grain yield (kg/ha) } & \multicolumn{3}{|c|}{ Duration (days) } \\
\hline & & & $\begin{array}{c}\text { AD } \\
09367\end{array}$ & $\begin{array}{c}C R \\
1009\end{array}$ & $\begin{array}{c}\text { ADT } \\
50\end{array}$ & $\begin{array}{c}\text { AD } \\
09367\end{array}$ & $\begin{array}{c}\text { CR } \\
1009\end{array}$ & $\begin{array}{c}\text { ADT } \\
50\end{array}$ \\
\hline 1 & $\begin{array}{l}\text { Station trials } \\
(2009-2011)\end{array}$ & 3 & 5682 & 5260 & 5682 & 151 & 152 & - \\
\hline 2 & $\begin{array}{l}\text { Multi location trials } \\
(2012-14)\end{array}$ & 9 & 7242 & 6778 & 6609 & 152 & 154 & 148 \\
\hline 3 & $\begin{array}{l}\text { Adaptive Research Trials } \\
(2014-16)\end{array}$ & 84 & 6357 & 6140 & 5725 & 146 & 150 & 146 \\
\hline 4 & KVKs (2014 -16) & 24 & 6206 & 5713 & 5741 & 152 & 157 & 148 \\
\hline \multirow[t]{3}{*}{5} & OFT (2014 -17) & 107 & 6709 & 5797 & - & 159 & 158 & - \\
\hline & Overall Weighted Mean & 222 & 6533 & 5947 & 5796 & 154 & 155 & 148 \\
\hline & $\begin{array}{l}\% \text { increase over the } \\
\text { checks }\end{array}$ & & 9.8 & 12.7 & & & & \\
\hline
\end{tabular}

Table 2. Distinguishing morphological characters of Rice ADT 51

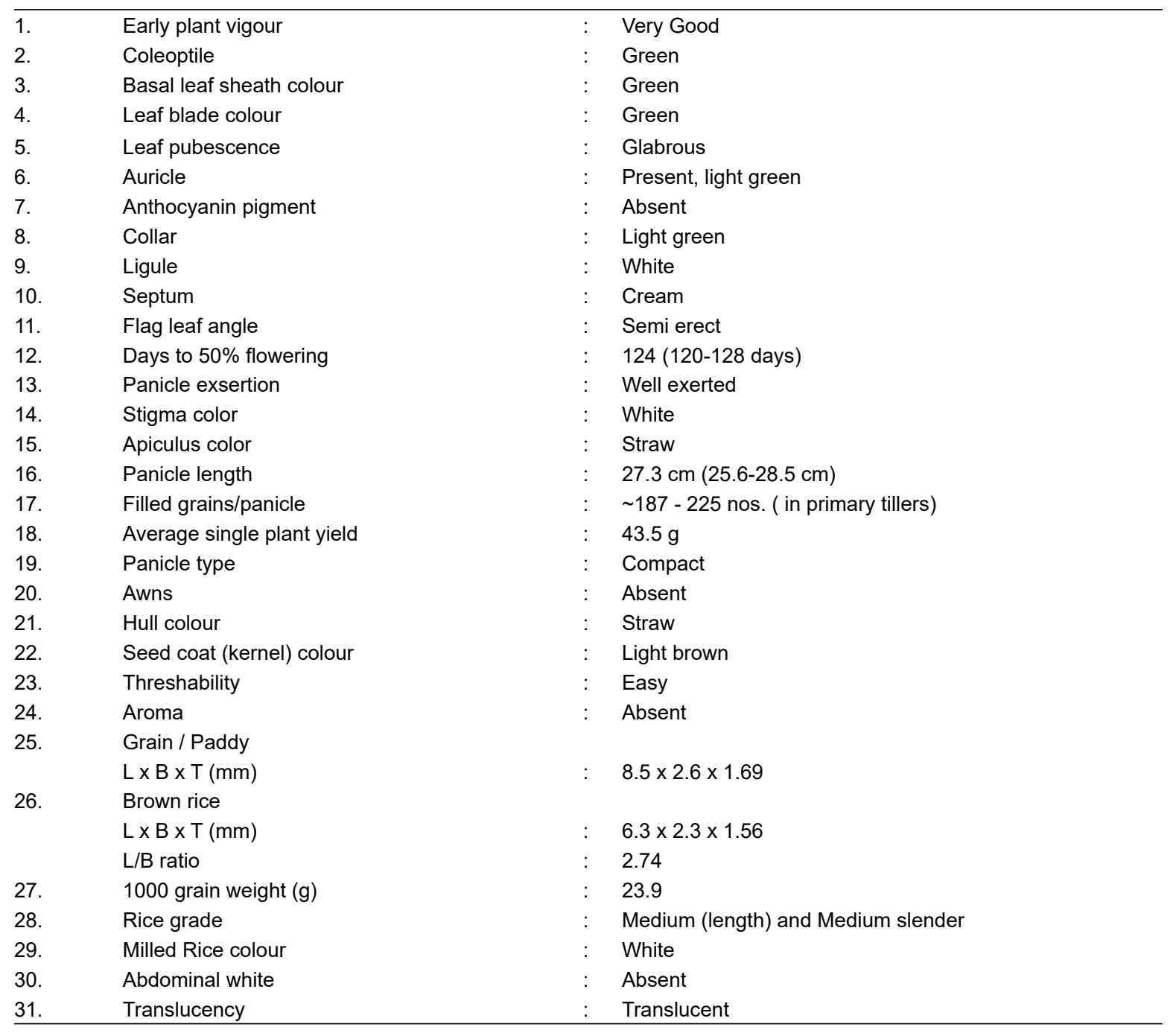

during 2014-15 and 2015-16 at Aduthurai, Coimbatore and Madurai. It is found to be resistant to Blast (scale 3), in 1 to 9 scale. This culture was found to be moderately resistant to bacterial leaf blight, sheath rot and brown spot (Table 3). It was also screened for major pests viz., brown plant hopper, stem borer, leaffolder and gal midge at Aduthurai, Coimbatore and Madurai. It shows moderate resistance to all the four pests for which it was screened (Table 4). 
Table 3. Reaction of AD 09367 to major Diseases (Average of two years 2013-14 \& 2014-15)

\begin{tabular}{|c|c|c|c|c|c|}
\hline $\begin{array}{l}\text { S. } \\
\text { No. }\end{array}$ & Diseases & Centre & AD 09367 & CR 1009 & ADT 50 \\
\hline 1. & Blast & CBE & 2 & 2 & 5 \\
\hline \multirow{2}{*}{2.} & \multirow{2}{*}{ Sheath rot } & ADT & 3 & 3 & 3 \\
\hline & & MDU & 5 & 7 & 9 \\
\hline \multirow{2}{*}{3.} & \multirow{2}{*}{ Sheath blight } & $\mathrm{ADT}^{*}$ & 5 & 7 & 5 \\
\hline & & MDU & 7 & 7 & 7 \\
\hline 4. & BLB & $\mathrm{ADT}^{*}$ & 3 & 7 & 7 \\
\hline 5. & Brown spot & ADT & 5 & 3 & 5 \\
\hline
\end{tabular}

${ }^{*}$ Artificial Screening

Source: TNAU Crop Scientists' Meet on Rice, 2014 \& 2015)

Table 4. Reaction to major Pests (Average of two years 2013-14 \& 2014-15)

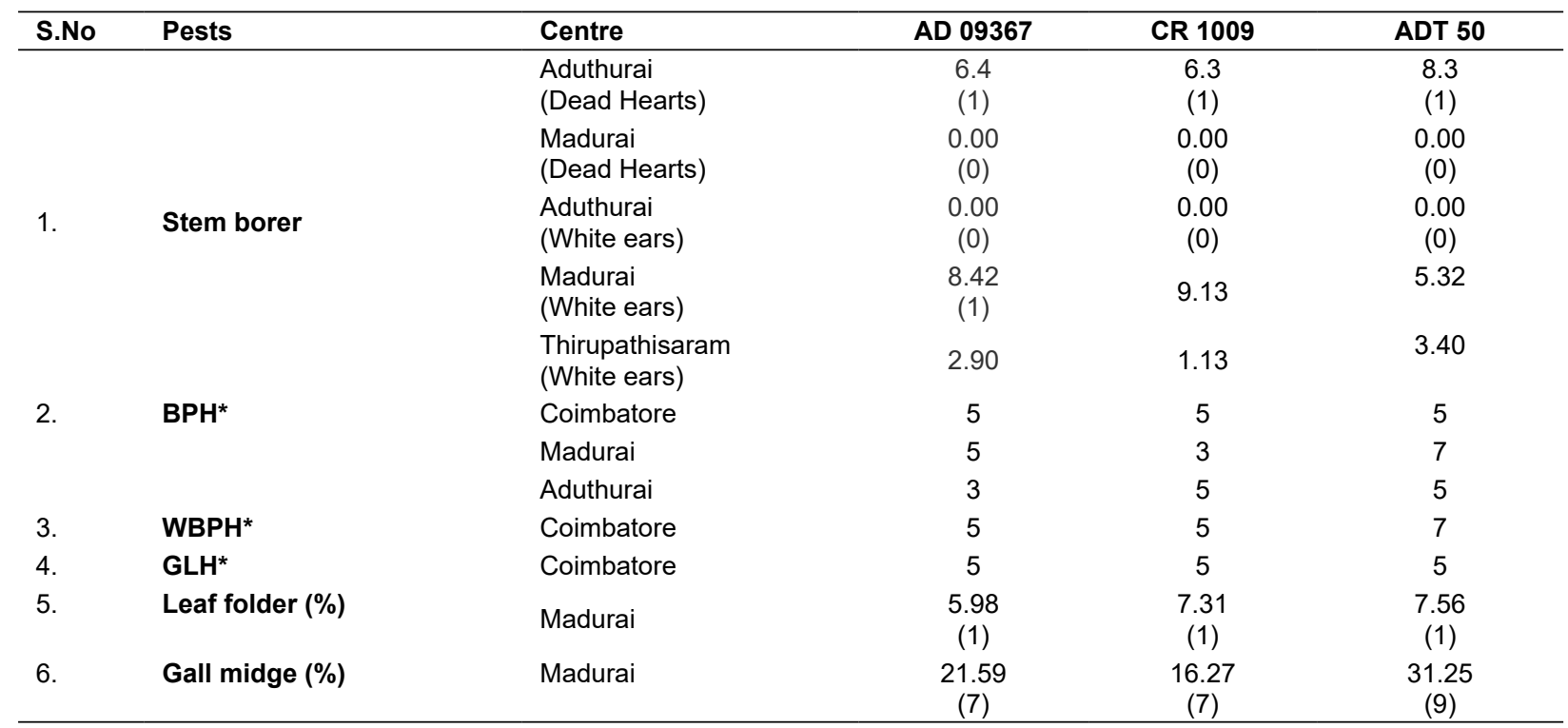

${ }^{*}$ Artificial Screening

Source: TNAU Crop Scientists' Meet on Rice, (2014 \& 2015)

Table 5. Physical quality characteristics (Average of two years 2013-14 \& 2014-15)

\begin{tabular}{lcccccc}
\hline Variety & $\begin{array}{c}\text { Milling } \\
\text { Yield } \\
(\mathbf{\%})\end{array}$ & $\begin{array}{c}\text { Head rice } \\
\text { Recovery (\%) }\end{array}$ & $\begin{array}{c}\mathbf{1 0 0 0} \text { grain } \\
\text { wt (g) }\end{array}$ & $\begin{array}{c}\text { Kernel } \\
\text { length } \\
(\mathbf{m m})\end{array}$ & $\begin{array}{c}\text { Kernel } \\
\text { breadth } \\
(\mathbf{m m})\end{array}$ & $\begin{array}{c}\text { L/B ratio } \\
{ }^{*} \text { Grain } \\
\text { Type }\end{array}$ \\
\hline AD 09367 & 70.3 & 60.5 & 23.90 & 6.3 & 2.3 & 2.74 \\
CR 1009 & 69.85 & 58.25 & 23.85 & 5.55 & 2.67 & 2.00 \\
ADT 50 & 68.20 & 56.0 & 16.00 & 5.45 & 2.05 & SB \\
\hline
\end{tabular}

${ }^{*}$ MS - Medium slender, SB - Short bold

Source: TNAU Crop Scientists' Meet on Rice, (2014 \& 2015)

Table 6. Cooking quality characteristics

\begin{tabular}{lccc}
\hline \multicolumn{1}{c}{ Parameters } & AD 09367 & CR 1009 & ADT 50 \\
\hline Kernel length after cooking $(\mathrm{mm})$ & 9.45 & 9.35 & 3.80 \\
Kernel breadth after cooking $(\mathrm{mm})$ & 3.2 & 3.0 & 1.0 \\
Linear elongation ratio & 1.56 & 1.73 & 1.32 \\
Breadthwise expansion ratio & 1.42 & 3.85 \\
Volume expansion (ml) & 3.85 & 3.39 & 3.45 \\
\hline
\end{tabular}

Source: TNAU Crop Scientists' Meet on Rice, (2014 \& 2015) 
Table 7. Organoleptic evaluation of cooked rice

\begin{tabular}{|c|c|c|c|}
\hline Characteristics & AD 09367 & CR 1009 & ADT 50 \\
\hline Appearance & 9.0 & 8.5 & 9.0 \\
\hline Cohesiveness & 9.0 & 8.0 & 9.5 \\
\hline Tenderness on touching & 7.8 & 7.0 & 9.0 \\
\hline Tenderness on chewing & 8.2 & 7.8 & 8.5 \\
\hline Taste & 7.5 & 7.5 & 8.0 \\
\hline Elongation & 7.3 & 6.0 & 8.5 \\
\hline Overall acceptability & 7.5 & 7.0 & 8.0 \\
\hline
\end{tabular}

Maximum score 10

The grain type of ADT 51 is medium slender with 1000 grain weight of $23.9 \mathrm{~g}$. Cooked rice is non sticky, soft with good taste and suitable for tiffin and savories preparation. The milling yield $(70.3 \%)$ and head rice recovery $(60.5 \%)$ of this culture are high and on par with CR 1009. Cooking quality and organoleptic characters are also similar to CR 1009 (Table 5, 6 \& 7)

Besides its yield superiority, AD 09367 was found to be resistant to blast and moderately resistant to insects like leaf folder, stem borer and BPH and diseases like sheath blight and sheath rot and field tolerance to all other major pests and diseases. Opinion from farmers revealed that, this culture fetches higher returns when compared to CR 1009 due its high yield potential with medium slender grain type. In addition, farmers also express that vigorous growing nature of this culture along with its field tolerance to major pest and diseases paves way to incur less expenditure for cultivation by applying less inputs especially nitrogenous fertilizer and plant protection chemicals. The characters such as quick seedling establishment, more number of productive tillers, less chaffiness are its added advantages. As a result, new rice variety "ADT 51" with higher yield, pest and disease resistance with superior cooking quality in comparison to the check CR 1009 was released during 2018 and it can be cultivated as a transplanted/direct seeded semidry crop during Samba season in the Cauvery Delta districts.

\section{REFERENCES}

INDIASTAT,2015. Socio-economicstatisticalinformationabout India. Online databases.In: http://www.indiastat. com/agriculture/2/commercialcrops/17188/ totalcommercialcrops/17203/stats.aspx.

Sushil Pandey, Derek Byerlee, David Dawe, Achim Dobermann, Samarendu Mohanty, Scott Rozelle, and Bill Hardy, editors. 2010. Rice in the global economy: strategic research and policy issues for food security. Los Baños (Philippines): International Rice Research Institute. 477 p.

K. Muralidharan, G. S. V. Prasad, C. S. Rao and E. A. Siddiq. 2019. Genetic gain for yield in rice breeding and rice production in India to meet with the demand from increased human population. Current Science, 116(4): 544-560. [Cross Ref]

C. S .Lin, M. R. Binns and L. P. Lefkovitch. 1986. Stability analysis: Where do we stand? Crop Sci., 2: 894900. [Cross Ref] 